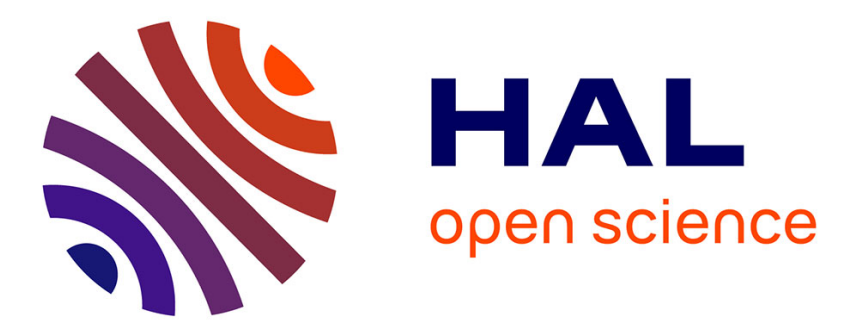

\title{
Endoscopic breast surgery: where are we now and what might the future hold for video-assisted breast surgery?
}

Daniel Richard Leff, Rajiv Vashisht, Gabriella Yongue, Mohammed Keshtgar, Guang-Zhong Yang, Ara Darzi

\section{- To cite this version:}

Daniel Richard Leff, Rajiv Vashisht, Gabriella Yongue, Mohammed Keshtgar, Guang-Zhong Yang, et al.. Endoscopic breast surgery: where are we now and what might the future hold for video-assisted breast surgery?. Breast Cancer Research and Treatment, 2010, 125 (3), pp.607-625. 10.1007/s10549010-1258-4 . hal-00597957

\section{HAL Id: hal-00597957 \\ https://hal.science/hal-00597957}

Submitted on 3 Jun 2011

HAL is a multi-disciplinary open access archive for the deposit and dissemination of scientific research documents, whether they are published or not. The documents may come from teaching and research institutions in France or abroad, or from public or private research centers.
L'archive ouverte pluridisciplinaire HAL, est destinée au dépôt et à la diffusion de documents scientifiques de niveau recherche, publiés ou non, émanant des établissements d'enseignement et de recherche français ou étrangers, des laboratoires publics ou privés. 


\section{Endoscopic Breast Surgery: \\ Where are we now and what might the future hold for video-assisted breast surgery?}

Daniel Richard Leff (MB BS, MRCS Eng, PhD) ${ }^{1,3}$, Rajiv Vashisht (MBBS, FRCS MPhil, FICS $^{3}$, Gabriella Yongue ${ }^{2}$, Mohammed Keshtgar (BSc, MB BS, FRCSI, FRCS (Gen), $\mathrm{PhD})^{4}$, Guang-Zhong Yang $(\mathrm{PhD})^{1}$ and Ara Darzi (MD MRCS FACS FMedSci KBE) ${ }^{1}$

${ }^{1}$ Department of Biosurgery and Surgical Technology, and Royal Wolfson Medical Image Computing Laboratory, Imperial College London;

${ }^{2}$ Imperial College School of Science, Technology and Medicine, Imperial College London;

${ }^{3}$ Departments of Breast and General Surgery, West Middlesex University Hospital NHS Trust;

${ }^{4}$ The Breast Unit, Academic Department of Surgery, Royal Free Hospital, London.

\section{Corresponding Author}

\section{Mr Daniel Richard Leff MBBS MRCS Eng PhD}

Academic Clinical Lecturer in General Surgery,

Department of Biosurgery and Surgical Technology,

The 10th Floor, QEQM Wing,

St Mary's Hospital,

Paddington, London. W2 1NY

Tel: +44(0)7515 257731

Email: d.leff@imperial.ac.uk

Running Head: $\quad$ Endoscopic Mastectomy: Where are we now and what does the future hold?

Word Count: $\quad$ abstract $=181$, paper $=4,753$

Article Category: $\quad$ Systematic Review

Financial Support: $\quad$ None to declare

Conflict of Interest: $\quad$ None to declare 


\begin{abstract}
$\underline{\text { Abstract }}$
Endoscopic surgery has been extensively used for many surgical conditions and has gained acceptance as an alternative and less invasive approach to open surgery. However, minimal access endoscopic techniques have yet to be translated into mainstream clinical practice in breast surgery. More recently, technical innovations have made it feasible to conduct endoscopic breast cancer resection, with or without breast reconstruction, through wounds inconspicuously hidden in the axilla and periareolar region. Several clinical trials have now been conducted to demonstrate technical feasibility, assess safety and provide follow up data regarding oncological success of endoscopic breast surgery. This primary aim was to critically evaluate the literature in order to determine the oncological and cosmetic efficacy of endoscopic breast surgery. A systematic review was conducted using Medline, Ovid and Embase to identify original data from studies of endoscopic breast surgery. Initial results have demonstrated that endoscopic breast surgery is safe and technically feasible. Early data suggests that it is possible to achieve disease control with high rates of overall survival and low rates of local relapse recurrence and/or distant metastases. However, the absence of level I randomised clinical evidence currently precludes a recommendation that endoscopic breast cancer surgery is capable of achieving equivalent oncological outcomes to open surgery.
\end{abstract}

Abbreviations: skin sparing subcutaneous mastectomy (SSM); endoscopic subcutaneous mastectomy (ESM); video-assisted breast surgery (VABS); breast conserving surgery (BCS); sentinel lymph node biopsy (SLNB); axillary lymph node dissection (ALND); ductal carcinoma in situ (DCIS); lobular carcinoma in situ (LCIS); invasive ductal carcinoma (IDC). 


\section{Introduction}

Minimal access endoscopic techniques have transformed many fields of surgery through the provision of improved body cavity access, enhanced visualisation via magnification, and minimisation of tissue trauma. Breast cancer surgery, however, represents a major field of surgical oncology in which endoscopy has yet to be adopted in mainstream clinical practice. This may be due to the fact that breast surgery is inherently low morbidity, results in low levels of pain, and that breast tumours can commonly be accessed through small incisions [1]. However, in cases where mastectomy is deemed necessary, a more extensive incision is required which is detrimental to cosmesis and body image. Theoretically, if endoscopic mastectomy combined with immediate breast reconstruction (IBR) could be proven to be oncologically safe, there may be tremendous gains in terms of reducing surgical morbidity and improved aesthetics.

Mastectomy techniques have undergone a significant improvements since William Halstead first proposed the radical mastectomy in 1891 [2]. By 1948, a less radical approach to mastectomy, preserving the pectoralis muscle and overlying skin without compromising oncological quality had been proposed by Patey and Dyson [3]. More recently, Toth and Lappert developed the technique of skin sparing subcutaneous mastectomy (SSM) in order to preserve skin and facilitate breast reconstruction without adversely affecting oncological safety [4]. Therefore, endoscopic mastectomy represents a minimally invasive approach in a field of surgical oncology with the aim of complete cancer clearance and preservation or restoration of the patient's body image. Endoscopic subcutaneous mastectomy (ESM) may particularly benefit women with small breasts in whom breast conserving surgery (BCS) may result in obvious breast asymmetry, inadequate resection margins and poor cosmesis [5] and therefore the main protagonists of ESM have been in Asian countries such as Japan, Korea and China. Despite the appeal of ESM, concerns surrounding endoscopic breast cancer resections relate to the 
oncological safety, the additional cost in terms of operative time, equipment and training, as well as the wider applicability for patients with larger breast volumes $[1,5,6]$. Some surgeons have even suggested that ESM may not be justified if it is merely to reduce the size of the scar on the breast [1].

The aim of the current systematic review is to evaluate the evidence for full and partial ESM. We will also evaluate different operative techniques and assess oncological safety in terms of adequacy of tumour margins, rates of local recurrence and distant metastases, as well as overall survival (OS) and disease free survival (DFS). Moreover, surgical morbidity, cosmetic outcomes and economic cost implications associated with ESM with IBR are evaluated and compared to simple mastectomy and open SSM. Although reviews and editorial comment pertaining to ESM do exist in the literature $[1,5,6]$, they are either not sufficiently systematic in nature $[1,5]$, or have been outdated by virtue of the pace of technological developments which have enabled simplification of endoscopic techniques [6].

Description of the Operative Techniques for Endoscopic Breast Conserving Surgery and Endoscopic Subcutaneous Mastectomy

Table 1 outlines a number of different techniques described for endoscopic partial or total subcutaneous mastectomy. Regardless of the differences between techniques in terms of the devices used for endoscopic visualisation, dissection and specimen retrieval, there is uniformity in many aspects of the procedure. Patients are typically placed in the supine position on the operating table, with the surgery-side arm placed at $90^{\circ}$ to extend the axilla. Tumour localisation is usually achieved via a combination of palpation and radiological guidance, with the proposed resection margins being marked preoperatively 
on the patient's skin surface. For partial mastectomy and endoscopic BCS, identification of the proposed resection margins may be further enhanced by the appearance of dye injected at several points at the tumour periphery. Skin incisions are placed in either a periareolar location or in the axilla, working planes are achieved by subcutaneous and sub-mammary elevation, balloon dissection and/or retractors. Endoscopic dissection is performed between the posterior breast and pectoralis fascia, between the breast and subcutaneous tissue and along the lateral and medial resection margins, haemostasis being achieved through ligation and electrical coagulation. Finally, the specimen is retrieved via one of the port sites for histological assessment. Each stage of endoscopic subcutaneous breast resection is discussed in the following section with the aim of highlighting the different technical approaches attempted to date.

\section{Incision placement}

Axillary incisions are the most common point of access to facilitate endoscopic subcutaneous full or partial mastectomy as well as axillary node biopsy, which can be performed either endoscopically or under direct vision. The length and number of axillary incisions varies, with some surgeons being able to proceed through a small single axillary point of entry[7-9], whilst others require lengthier incisions $(\sim 8 \mathrm{~cm})[10]$ or multiple axillary incisions seemingly to mirror the triangulation set-up of traditional abdominal laparoscopy [11-13]. Additional periareolar incisions are adopted for cases in which tumours are located in the inner breast quadrant [14-16] to facilitate subcutaneous dissection [17] or if the patient's breasts are especially large [18]. Finally, depending on tumour location, it may be necessary to place incisions in the infra-mammary crease [10]. 


\section{Wound protection}

The use of a wound protector was infrequently reported and when a device was employed, justification for its use was often not explicit [7-9, 19]. The device most commonly used was 'Lap Protector' (Hakko Co), which consists of two flexible rings made of super elasticity alloys covered with polyurethane polyamide, and a thin silicone rubber membrane that is attached to the outer rim of the two rings. If the two rings are pulled apart the device assumes a cylindrical shape. The device is more commonly used in laparoscopic colorectal cancer surgery to prevent wound contamination with bacteria and cancer cells leading to infection and port site metastases respectively.

\section{Endoscopic visualisation}

The majority of authors describe introducing the endoscope through the channel of a bladeless trocar such as ENDOPATH (Johnson \& Johnson Medical Arlington, TX) or VISIPORT PLUS (United States Surgical, Norwalk, CT, USA) which enables placement of the visualisation system within tissues under direct vision $[8,10,15,16,20,21]$. The majority of surgeons employed a $10 \mathrm{~mm}, 0^{\circ}$ endoscope (Olympus, Co) as the visualisation system of choice. However, $5 \mathrm{~mm}$ and $30^{\circ}$ endoscopes have been used without any obvious increase in adverse events or ergonomic challenges [7, 17, 18, 21].

\section{Methods of creating and maintaining an endoscopic work space}

Broadly, there are three methods for creating and maintaining a suitable endoscopic work space to facilitate resection, including inflation of the subcutaneous tissue using carbon dioxide $\left(\mathrm{CO}_{2}\right)$ to maintain a pressure of $\sim 8 \mathrm{mmHg}[11-13,19]$, the use of dissecting balloons (e.g. PDB) [10-12, 19] as illustrated in Figure 1, and tissue elevation either in the form of anchoring sutures [7, 8] or using specific fit for purpose retractors [22, 23] such as the HIROTECHretractor [15, 16] or Clearglide dissector, as depicted in Figure 2. 
The most commonly employed technique is known as the 'subcutaneous tunnelling method' $[7,8,10,15,16,21,24]$. This method involves creating a number of subcutaneous tunnels using the endoscopic or bladeless trocar. The septa between the tunnels are then dissected under endoscopic guidance using either electric or harmonic scalpels and/or powerstar bipolar scissors.

\section{Techniques for endoscopic posterior breast dissection}

The use of a retraction device (e.g. Ultra Retractor, HIROTECH retractor, Endoscopic Breast Retractor, etc) appears to significantly improve visualisation and aids dissection of the posterior aspect of the breast from the pectoralis fascia (see Figure 2) [7-9, 15-18, 22, 23, 25]. However, the successful use of balloon dissection has also been reported [10, 24]. Tissue dissection and vessel coagulation is achieved using a harmonic scalpel, ultra retractor vein harvest, and/or powerstar bipolar scissors.

\section{Specimen retrieval}

The resected breast specimen is retrieved directly through the axillary or periareolar port sites, with the wound occasionally needing extension to facilitate retrieval. A few authors described the use of a sterile bag device (e.g. 'Endocatch') to aid specimen retrieval and to prevent unnecessary contact between malignant breast cancer cells and the skin $[7,8$, $12]$. 


\section{Materials and Methods}

\section{Literature Search Criteria}

The literature search was performed using Medline, Ovid, Embase, and Cochrane databases. The following MeSH headings were used: "Endoscopy", "Mastectomy", "Video-assisted surgery”, "Breast”, "Breast Surgery”, "Carcinoma” and "Cancer". The related articles function was utilised to broaden the search, and all abstracts, studies, and citations were scanned and reviewed. The bibliography of the acquired articles was also searched manually. Studies were limited to those in the English language. The latest date for this search was $1^{\text {st }} \operatorname{March} 2010$.

\section{Data Extraction}

Two reviewers (D.R.L and G.Y), independently extracted the following data from each study: first author, year of publication, study population characteristics, study design, number of subjects, and outcome measures. Two reviewers (D.R.L. and G.Y.) extracted or calculated the rates of loco-regional disease recurrence, metastatic disease recurrence, and overall survival. Three authors (D.R.L., R.V. and R.K.) critically reviewed the design limitations of each study.

\section{Inclusion and Exclusion Criteria}

In order to enter our review, studies had to be clinically orientated (defined as involving human patients) and utilise endoscopic techniques or video assistance to guide resection of a specific volume of breast tissue or the entire breast as the primary surgical treatment of neoplastic breast lesions (benign and malignant). Non-human studies and those involving endoscopic methods to treat non-cancer related breast disease (e.g. gynaecomastia) or involving reconstruction in the absence of neoplastic resection were all excluded. 


\section{Results}

\section{Study Identification}

The systematic search strategy is summarised in Figure 3. 185 publications were identified in the initial search. 171 articles were excluded following title and abstract review. This included 9 relevant articles written in foreign languages, 25 articles pertaining to endoscopic primary breast augmentation or gynaecomastia surgery, 14 papers related to other breast surgical techniques (e.g. mammaplasty), 16 articles related to ductoscopy, 1 article involving non-human data, 1 editorial commentary, 14 review papers and 91 papers unrelated to breast surgery. This resulted in 14 studies that were investigated in detail. Examination of the references revealed a further 5 studies that fulfilled the inclusion criteria. In total, this left 19 studies for inclusion and data extraction. Study synopses of the included articles are summarised in Table 2. In total, 1, 389 patients have undergone ESM or endoscopic BCS for neoplastic breast lesions.

What are the patient and tumour-specific factors that define eligibility for endoscopic mastectomy / endoscopic breast conserving surgery?

The primary indication for endoscopic mastectomy is extensive ductal carcinoma in situ and early invasive breast cancer (T1/T2), particularly in women with smaller breasts in whom breast conserving surgery (BCS) may result in obvious deformity[5]. Tumour size appears to be the single most important eligibility criteria defining entry into endoscopic mastectomy trials. Several researchers have limited their trials of endoscopic breast cancer surgery to T1 and small T2 tumours ( $<3 \mathrm{~cm}$ in size) $[14,18,21-23]$, whilst others have included patients with larger T2/T3 tumours $(>3$ but $<6 \mathrm{~cm}$ ) and/ or multifocal disease $[11,15-17,24]$. Patients with a distribution of invasive disease that would otherwise be suitable for standard BCS, but in whom post-operative radiotherapy was not deemed acceptable were also candidates for endoscopic mastectomy in certain trials [18]. 
Common exclusion criteria include the presence of nipple deviation or retraction or suspicion of nipple-areolar complex involvement detected clinically or radiologically [9, 13, 16-20], Paget's disease [17], obvious skin involvement [9, 15-17, 19-21], confirmation of distant metastasis [9, 13, 14], associated co-morbidity or poor performance status $[9,20]$, and in certain cases the presence of obvious axillary lymph node involvement $[9,13,21,23]$. In circumstances where endoscopic techniques were employed to achieve BCS, disease multifocality was also an exclusion criterion [21].

Do the results of current trials confirm the oncological safety of endoscopic mastectomy in terms of positive histological margins?

As with any new technique, concerns have been expressed regarding the ability of ESM to achieve local disease control. This is outcome measure is extremely important as positive margins not only herald local recurrence but also increase the likelihood of postoperative radiotherapy threatening the cosmetic outcome and negating the benefits of a minimal access approach. Taking this into account, surprisingly $47.3 \%$ of the reviewed papers failed to provide data on the ability of ESM / endoscopic BCS to achieve complete histological excision (Table 3 and 4) [8, 11-14, 20, 22, 25]. Only one non-randomised study [19] has compared the rates of local margin involvement between endoscopic and open subcutaneous mastectomy for breast cancer. Kitamura et al [19] were unable to demonstrate a statistically significant difference in the rate of local margin involvement following open and endoscopic subcutaneous mastectomy (open versus endoscopic = $8.0 \%$ versus $4.8 \%, \mathrm{p}=0.1851)$.

Of even greater concern is the wide range of positive histological margins (3-24\%) observed amongst studies that do report data for this endpoint $[9,15,16,19,21,23,24]$. The reasons for failure to obtain adequate tumour margins at the time of endoscopic 
breast resection are likely to be multifactorial, although learning curve, tumour multicentricity and sub-radiological disease foci may be contributory. Nakajima et al [15] subcategorised margin involvement by tumour size demonstrating an increasing probability of margin involvement for in situ disease (Tis=34\% versus T2=19.2\%), and by tumour stage demonstrating a similar likelihood of margin involvement between stage I and II disease (stage $\mathrm{I}=12.8$ versus stage $\mathrm{II}=15.3, \mathrm{p}=\mathrm{NS}$ ) [16]. However, since all the studies reporting margin involvement limited ESM recruitment to patients with T2 disease, tumour size may not rationally explain the variation in positive margin involvement between studies. It appears that margin involvement is in part explained by the type of technology, operator experience and patient volume, with lower rates of margin involvement in studies involving larger cohorts (Table 3 and 4).

Table 5 highlights the rates of positive margin involvement following subcutaneous mastectomy and nipple sparing mastectomy. It is evident that rates of margin positivity are an under-reported endpoint per se. Nevertheless, margin positivity rates where reported, have been observed to be as low as $0.3 \%$ in recent large series of SSM [26] and ESM has yet to replicate this accuracy in terms of oncological clearance. Moreover, there have been no randomised controlled trials comparing ESM to open SSM and / or NSM therefore there is an absence of level I evidence available to definitively demonstrate the oncological safety of ESM. 
Is endoscopic mastectomy associated with an increased risk of local and/or distant disease recurrence and poorer overall survival?

\section{a) Local recurrence}

The local recurrence rate (LR) following endoscopic breast cancer surgery is infrequently reported in papers describing novel endoscopic methodologies as these studies were not designed to collect prospective follow-up data $[8,11,14,18,20-22,25]$. In eight studies, following an average follow-up duration of 24.1 months there was no reported LR [7, 9, $11,13,17,19,23,24]$. However, notwithstanding some exceptions [17, 24], the average duration of follow-up has been less than two years and investigators have observed LR following endoscopic resection when follow-up is extended beyond three years [15]. Only two non-randomised studies have compared the rates of LR between patients undergoing endoscopic subcutaneous mastectomy versus open breast conserving surgery [13] and versus open subcutaneous mastectomy [19]. Fan et al [13] failed to observe any significant difference in the rate of LR between patients undergoing endoscopic breast resection and those undergoing breast conservation following an average follow-up duration of 16.9 months $(\mathrm{LR}=\mathrm{BCS}$ versus $\mathrm{ESM}=1.9 \%$ versus $0 \%, \mathrm{p}=0.247)$. Similarly, following an average of 19.2 months follow-up Kitamura et al [19] failed to demonstrate clinical recurrence in patients undergoing subcutaneous mastectomy and reconstruction regardless of whether operative mode was open or endoscopic. One risk factor for the development of subsequent LR following endoscopic resection may be tumour size. Nakajima et al [15] recently demonstrated that LR was more likely following endoscopic resection of larger breast cancers $(\mathrm{Tis}=0, \mathrm{~T} 1=3.7 \%$ and $\mathrm{T} 2=5.1 \%$ ). The theoretical increased risk of LR following skin-side / muscle side positivity does not appear to be proven, and indeed Nakajima et al [15] were unable to demonstrate a statistically significant difference in the rates of LR between margin positive versus margin negative patients (LR rates $=4 / 113$ for margin $+v e$ versus $19 / 438$ for margin $-v e, p=N S)$. Finally, 
there have been no reports of local recurrence in the vicinity of axillary or peri-areolar incisions that would mirror port-site recurrence observed following laparoscopic cancer surgeries [27].

\section{b) Distant metastatic disease}

Five studies report rates for detection of distant metastatic disease over the duration of follow-up [13, 15-17, 19]. The rates of distant metastases detected over a mean duration of follow up of 38.3 months range from $4.5 \%$ to $10 \%[13,15-17,19]$. The study with the highest incidence of distant metastases detection was observed to have a significant proportion of node positive patients at the outset ( $41 \%$ axillary node positive), possibly contributing to the burden of distant disease recurrence[17]. Similarly, in the cohort study by Nakajima et al [15] the chances of subsequent distant disease detection were related to tumour size, which itself was observed to correlate with the risk of node positivity (metastases\%: Tis=0, T1=3.7, and $\mathrm{T} 2=5.7$; node $+\mathrm{ve} \%=\mathrm{Tis}=4.3, \mathrm{~T} 1=12.6$, and $\mathrm{T} 2=30.9$ ). However, in a cohort study of 244 patients undergoing endoscopic skin sparing partial mastectomy, the same authors were unable to demonstrate a statistically significant difference in the detection rate of distant metastases between stage I and stage II disease (metastases\%: stage $\mathrm{I}=6.4$ versus stage $\mathrm{II}=10, \mathrm{p}=\mathrm{NS}$ ) [16]. Two non-randomised studies involving a combined total of 143 patients have failed to demonstrate a statistically significant difference between endoscopic and open breast cancer resection in terms of the likelihood of developing subsequent metastatic disease [13, 19]. However, the duration of follow-up reported in these non-randomised trials is relatively short (average follow-up $=16.9-19.2$ months). 
c) Overall survival (OS)

Results from two non-randomised studies suggest that the overall survival (OS) following endoscopic and open breast cancer resection for early stage disease is comparable over a maximum average follow-up duration of 19.2 months $[13,19]$. Other cohort studies with follow-up durations ranging from 12 months to approximately 4 years suggest excellent OS following endoscopic breast cancer resection $(100 \%)$ [7, 24]. Nakajima et al [16] were unable to demonstrate a significant difference in OS between patients with stage I and stage II disease, but variation in OS was influenced by tumour size $(\mathrm{OS} \%=$ Tis $=100$, $\mathrm{T} 1=97.3, \mathrm{~T} 2=95.7)$.

\section{Peri-operative and post-operative morbidity}

\section{a) Intra-operative blood loss}

The mean volume and weight of intra-operative blood loss following endoscopic breast cancer resection across all trials is $189 \mathrm{ml}$ and $84.4 \mathrm{~g}$ respectively. In the non-randomised trial by Kitamura and colleagues, the volume of intra-operative blood loss was significantly $(\mathrm{p}<0.05)$ greater following endoscopic subcutaneous mastectomy and reconstruction versus the open equivalent [19]. Conversely, the volume of intra-operative blood loss and post-operative drainage were not found to be significantly different between the patients undergoing endoscopic subcutaneous mastectomy versus open BCS in another prospective non-randomised trial [13]. The results of the latter study by Fan et al [13] are especially relevant as the BCS group would have undergone a more conservative dissection, and therefore one would have anticipated greater intra-operative blood loss in the group undergoing mastectomy. 


\section{b) Skin, muscle and nipple necrosis, and prostheses-related complications}

The two non-randomised clinical studies observed a similar overall complication rate following endoscopic and open breast cancer surgeries, but the nature of the complications varied depending upon operative mode [13, 19]. Complications observed by Kitamura et al [19] were predominantly prosthesis related, and these were significantly more common in patients treated with conventional subcutaneous mastectomy $($ endoscopic $=4.8 \%$ versus open $=12 \%, \mathrm{p}=0.4)$. Similarly, three patients treated with conventional breast surgery experienced capsular contractures whereas no patients treated with endoscopic mastectomy and reconstruction experienced this complication [19]. All the complications in the open surgical group treated by Fan et al [13] were related to hydrops all of which required repeat needle puncture and aspiration $(n=6 / 54)$. Hydrops was not observed in the group treated endoscopically, however patients in this group were observed to experience skin blistering and necrosis of the nipple areolar complex (overall complication rate $=5 / 43$ )[13]. Complications associated with ESM that were not infrequently observed in cohort studies and case series include skin and muscle flap necrosis, superficial and deep skin burns associated with the use of electrocautery [9, 13, 15-17], skin bruising and subcutaneous emphysema [11, 12]. Infection and haematoma were complications rarely observed following endoscopic breast cancer surgery. Interestingly, there have been no studies comparing levels of pain and analgesic requirements between patients treated with conventional versus minimal access endoscopic breast surgery. 
Does endoscopic mastectomy offer superior cosmesis compared to conventional mastectomy?

Endoscopic mastectomy, especially if combined with IMBR results in minimal scarring and restoration of breast volume. Similarly, endoscopic BCS with reconstruction may result in excellent cosmesis, as illustrated in Figure 4. However, as highlighted in Table 3, there was a considerable range of methods used for reporting satisfaction with the cosmetic result following endoscopic breast surgery. Some investigators merely reported whether or not patients were 'satisfied' with the final outcome [12, 14, 22, 23], others employ more objective methods including self satisfaction indices and rating scales anchored with specific descriptors $(0-3=$ poor-excellent $)[13,15,16,19,21]$ or used a sub classification system such as the asymmetry, breast shape, nipple shape, skin condition and wound scar (ABNSW system) [7-9]. From the reviewed data, the majority of patients who have undergone endoscopic breast resection are satisfied with the cosmetic outcomes. In only two studies was the cosmetic outcome following endoscopic surgery compared to that achieved following conventional open resection $[13,19]$. The authors failed to observe a statistical difference in patient's self-reporting of cosmetic outcomes at six months or more following open and endoscopic breast surgery $[13,19]$. However, in the study by Kitamura and colleagues [19] there was a trend towards superior cosmetic outcomes following endoscopic subcutaneous mastectomy and reconstruction with $85.6 \%$ reporting excellent outcomes following endoscopic resection compared to $60.0 \%$ after open breast surgery. Interestingly, Fan et al [13] did not observe a high rate of patient satisfaction with only $20.9 \%$ reporting 'excellent' results following endoscopic subcutaneous mastectomy and immediate implant reconstruction. Notwithstanding this, the overall cosmetic satisfaction rate was comparable to patients treated in the open BCS study arm [13]. 
Is endoscopic breast surgery cost effective?

There have been no randomised or non-randomised studies specifically comparing the cost-effectiveness of open versus endoscopic breast cancer surgery. As Table 2 highlights, average operating times required for endoscopic breast cancer surgery are longer than those for open surgery. Only three studies [9, 13, 19] incorporated comparative data on the average operative durations for endoscopic and open breast resection (average operating time, mean \pm SD $=$ ESM: 192.6 \pm 38.5 versus Open: 154.6 \pm 19.1 minutes). Therefore, our calculations suggest that an endoscopic approach adds on average approximately 38 minutes to the operating time (192.6-154.6=38.0). This is likely to have significant repercussions on theatre productivity and capacity to meet national targets for cancer treatments. Not only is operating time expensive, but the instrumentation would add considerably to the costs [1]. Although the current review has failed to find objective data comparing equipment costs, Kitamura et al [19] estimated that endoscopic lumpectomy would cost approximately $\$ 1,150$ for one hospital stay versus $\$ 500$ for the conventional open surgical procedure [19]. In our opinion, this represents a gross underestimate of the additional costs required to support an ESM breast service. Training in performing endoscopic breast surgery is paramount to oncological and cosmetic success and inevitably involves significant investments in terms of time and finances to train and certify surgeons and theatre nurses. Finally, the cost involved in failure of endoscopic mastectomy, conversion to open mastectomy and salvage open mastectomy for margin involvement needs to be configured into any future formal cost analysis. 


\section{$\underline{\text { Discussion and Conclusions }}$}

As endoscopic breast resection is still in its infancy, it is unsurprising that data supporting the efficacy of the endoscopic and video assisted breast cancer surgery is relatively sparse. In fact, there is a lack of high quality randomised clinical trials providing level I evidence in support of ESM and endoscopic BCS. The data that are available are from case series, cohort studies and non-randomised trials, and these provide level II-IV evidence in support of ESM techniques. This is compounded by the fact that comparative data is between ESM and open BCS [13], when perhaps a more suitable comparison would be open SSM with retro pectoral implant reconstruction. The current paper has reviewed the evidence for ESM and endoscopic BCS in order to evaluate case selection, morbidity and mortality, oncological success, cosmetic acceptability and cost efficiency of endoscopic breast cancer surgery.

As with many new technologies, case selection for ESM appears to be critical, hinging on identifying patients with either early T1/2 tumours or high grade DCIS in whom conventional open BCS is either inappropriate or likely to lead to significant volume loss and unsatisfactory cosmetic results, or in patients who wish to avoid post-operative radiotherapy. ESM may be preferable for multifocal tumours where breast conservation is not suitable. However, disease multicentricity has typically been an exclusion criterion in most ESM trials and there is no current evidence to support the use of ESM in patients with multifocal disease. Similarly, some protagonists state that tumour size and position should not pose restriction on suitability for ESM providing the skin and primary duct are cancer free [13]. However, patients with large tumours are typically excluded from endoscopic breast surgery trials. Therefore, future studies will need to objectively assess the suitability of ESM in patients with large tumours, disease multifocality and larger 
breasts in whom conventional open BCS may not necessarily result in significant deformity.

Endoscopic breast surgery appears to be well tolerated and a relatively safe technique. Complications commonly observed following open breast surgery; in particular seroma (hydrops) formations, haematoma, infection and prosthesis-related complications are less frequently encountered following ESM. However, certain complications are more frequently observed following ESM and include: skin bruising and blistering from electrocautery, skin and muscle flap necrosis, and necrosis of the nipple areolar complex. Furthermore, there is some evidence to suggest that ESM may be associated with greater intra-operative blood loss than open breast surgery [19]. It is possible that these complications are related to the learning curve and/or limitations of current endoscopic instruments, influenced by training and technological advances respectively. For example, Fan et al [13] observed a reduction in the incidence of nipple areolar complex necrosis by reversing the tip of the suction nozzle away from the skin and subcutis. Interestingly, we were unable to identify studies comparing post-operative pain levels and analgesic requirements between open breast surgery and ESM. Theoretically, by significantly reducing the size of the operative incision, the pain and analgesic requirements following ESM should be substantially lower, but this clearly needs to be evaluated systematically and objectively.

For endoscopic breast cancer surgery to gain acceptance in clinical practice, it must demonstrate itself to be at least as efficacious as open surgery in terms of oncological success. From the reviewed data it is evident that endoscopic breast resection either as ESM or BCS is capable of achieving local disease control in the majority of patients. However, rates of positive margin involvement are at best highly variable (3-24\%) and at 
worst not yet comparable to those achievable with open SSM and NSM (Table 5). Therefore, one must conclude that at the current time, the rates of positive margin with ESM are not reproducibly low enough, even if margin positivity is not the only factor contributing to local failure [16]. This is extremely important as margin positivity resulted in patients necessitating additional therapies including revision surgery such as primary or secondary NAC excision [24], salvage mastectomy [21] as well as unplanned radiotherapy [19].

Data from non-randomised studies provide limited evidence to suggest an equivalent risk of developing LR and distant metastatic disease following endoscopic breast resection and open breast cancer surgery $[13,19]$. The risk of developing LR and distant disease appears to relate more to clinical / pathological tumour characteristics (e.g. size, grading, etc) [15] rather than the mode of operative intervention. However, follow-up for detection of LR and disease recurrence has rarely extended beyond two years, which in our view is too short to demonstrate comparable oncological outcomes with open surgery. The same argument could be levelled at the data pertaining to OS, which although encouraging (> 95\% following an average follow-up of 19.2 months) is not supported by long-term results.

Those who champion endoscopic breast cancer surgery argue that one of the primary advantages of ESM with immediate breast reconstruction (IMBR) is restoring the patient's body image and improving cosmesis over open BCS. The majority of revised studies include some reference to the patients' overall satisfaction with the outcome, but it is not always transparent how this assessment was obtained, whether or not these assessments were subjective and how if at all bias was minimised. Perhaps rather disappointingly, comparative data relating to cosmetic satisfaction following ESM versus 
open breast cancer surgery has failed to demonstrate the superiority of endoscopic surgery. In fact, in one comparative study, the rates of cosmetic satisfaction were actually worse for ESM (88.4\%) versus open BCS (92.6\%) [13]. The reasons for this may include prosthesis deviation, asymmetry due large ptotic contralateral breast, and/or unrealistic expectations regarding outcomes following ESM with IMBR.

In summary, significant recent progress in the arena of minimal access breast surgery has demonstrated endoscopic breast cancer surgery to be technically feasible and relatively safe. Initial results are encouraging and suggest that obtaining equivalent oncological results to open surgery should be achievable. However, there is a lack of level I evidence in support of endoscopic breast cancer surgery and there is now an urgent need for high quality, randomised clinical studies to confirm oncological success and demonstrate superior cosmesis, patient satisfaction and quality of life. Even if ESM does not become routine practice, research in this arena is likely to yield improve instrumentation, with greater flexibility and new platforms for the delivery of chemotherapeutics, radiotherapy [28], and high intensity focused ultrasound (HIFU) therapy [29]. 
$\underline{\text { Table } 1 \text { Comparison between different endoscopic mastectomy techniques and instrumentation (1/2) }}$

\begin{tabular}{|c|c|c|c|c|c|c|c|}
\hline Author & Incision(s) placement & $\begin{array}{l}\text { Wound } \\
\text { protector }\end{array}$ & Method for creating work space & $\begin{array}{c}\text { Port / } \\
\text { Endoscope }\end{array}$ & $\begin{array}{c}\text { Subcutaneous dissection techniques / } \\
\text { instruments }\end{array}$ & $\begin{array}{c}\text { Posterior dissection } \\
\text { techniques / instruments }\end{array}$ & $\begin{array}{l}\text { Specimen } \\
\text { retrieval }\end{array}$ \\
\hline $\operatorname{Fan}[13]$ & $\begin{array}{c}3 \text { incisions each } 0.5 \mathrm{~cm}=\mathrm{AAL} \text {, axillary } \\
\text { transverse striation, and MAL }\end{array}$ & no data & insufflation of $\mathrm{CO}_{2}$, at $8 \mathrm{mmHg}$ & no data & $\begin{array}{c}\text { lipolysis solution, liposuction and } \\
\text { electric hook }\end{array}$ & $\begin{array}{c}\text { lipolysis solution, } \\
\text { liposuction and electric } \\
\text { hook }\end{array}$ & no data \\
\hline Ho[18] & $\begin{array}{c}5 \mathrm{~cm} \text { along lowest axillary crease, in } \\
\text { large breast add a periareolar }\end{array}$ & no data & no data & $10 \mathrm{~mm}, 30^{\circ}$ & direct vision, harmonic & $\begin{array}{c}\text { endoscopic breast retractor, } \\
\text { harmonic scalpel }\end{array}$ & axilla \\
\hline Ito[24] & axillary & no data & no data & $10 \mathrm{~mm}$ & tunnelling method, harmonic scalpel & PDB dissecting balloon & axilla \\
\hline Kitamura[11] & $\begin{array}{l}\text { infra mammary or axillary, } 12 \mathrm{~mm} \\
\text { centre and } \times 25 \mathrm{~mm} \text { either side }\end{array}$ & no data & $\begin{array}{c}\text { dissection balloon, } \mathrm{CO}_{2} \text { at } 5-6 \mathrm{~mm} \\
\mathrm{Hg}\end{array}$ & $5 \mathrm{~mm}$ or $3 \mathrm{~mm}$ & 5-10mm harmonic scalpel & 5-10mm harmonic scalpel & $\begin{array}{l}\text { via } 12 \mathrm{~mm} \\
\text { incision }\end{array}$ \\
\hline Kitamura[12] & $\begin{array}{l}\text { infra mammary or axillary, } 12 \mathrm{~mm} \\
\text { centre and } \times 25 \mathrm{~mm} \text { either side }\end{array}$ & no data & $\begin{array}{c}\text { dissection balloon, } \mathrm{CO}_{2} \text { at } 5-6 \mathrm{~mm} \\
\mathrm{Hg}\end{array}$ & $10 \mathrm{~mm}$ & 5-10mm harmonic scalpel & 5-10mm harmonic scalpel & $\begin{array}{l}\text { via } 12 \mathrm{~mm} \\
\text { endocatch }\end{array}$ \\
\hline Kitamura[19] & $6 \mathrm{~cm}$ MAL & $\begin{array}{l}\text { yes, lap } \\
\text { protector }\end{array}$ & $\begin{array}{c}2 \text { patients }=\text { insufflation of } \mathrm{CO}_{2}, 19 \\
\text { patients }=\text { retractor technique }\end{array}$ & no data & no data & no data & no data \\
\hline Lee[21] & $\begin{array}{l}2.5 \mathrm{~cm} \text { along lowest axillary crease, } \\
\text { semicircular periareolar }\end{array}$ & no data & no data & $\begin{array}{l}\text { visiport / } \\
5 \mathrm{~mm} 0^{\circ}\end{array}$ & tunnelling method, powerstar scissor & $\begin{array}{l}\text { vein harvest, powerstar } \\
\text { scissors }\end{array}$ & $\begin{array}{l}\text { axillary or } \\
\text { periareolar }\end{array}$ \\
\hline Nakajima[25] & 5-7cm MAL & no data & lifting fan & $10 \mathrm{~mm}$ & bipolar scissors under video guidance & vein harvest & no data \\
\hline Nakajima[16] & $\begin{array}{l}\text { lateral tumour - axilla, } \\
\text { medial tumour - circumareolar }\end{array}$ & no data & Hirotech retractor & $\begin{array}{c}\text { ENDOPATH / } \\
10 \mathrm{~mm}\end{array}$ & $\begin{array}{l}\text { tunnelling method, trabecula separated } \\
\text { using electric scalpel (MERA) }\end{array}$ & Hirotech retractor, & no data \\
\hline Nakajima[15] & $\begin{array}{l}\text { lateral tumour - axilla, } \\
\text { medial tumour - circumareolar }\end{array}$ & no data & Hirotech retractor & $\begin{array}{c}\text { ENDOPATH / } \\
10 \mathrm{~mm}\end{array}$ & $\begin{array}{l}\text { tunnelling method, trabecula separated } \\
\text { using electric scalpel (MERA) }\end{array}$ & Hirotech retractor, & no data \\
\hline Owaki[14] & $\begin{array}{l}5 \mathrm{~cm} \text { axilla, for inner quadrant tumour -- } \\
\text {-add a periareolar }\end{array}$ & no data & double retractor method & no data & no data & no data & no data \\
\hline Sakomoto[17] & $\begin{array}{l}3 \mathrm{~cm} \text { extending to } 5 \mathrm{~cm} \text { in axilla, } \\
\text { periareolar to facilitate subcut } \\
\text { dissection }\end{array}$ & no data & ultra retractor, lift method & $5 \mathrm{~mm}, 30^{\circ}$ & tunnelling method, powerstar scissors & $\begin{array}{l}\text { direct vision, ultra retractor, } \\
\text { power star scissors }\end{array}$ & $\begin{array}{l}\text { periareolar or } \\
\text { axilla }\end{array}$ \\
\hline
\end{tabular}


$\underline{\text { Table } 1 \text { continued }(2 / 2)}$

\begin{tabular}{|c|c|c|c|c|c|c|c|}
\hline Author & Incision(s) placement & Wound protector & $\begin{array}{c}\text { Method for creating } \\
\text { work space }\end{array}$ & Port / Endoscope & $\begin{array}{c}\text { Subcutaneous } \\
\text { dissection techniques / } \\
\text { instruments }\end{array}$ & $\begin{array}{c}\text { Posterior dissection } \\
\text { techniques / } \\
\text { instruments }\end{array}$ & Specimen retrieval \\
\hline Tamaki[22] & $5 \mathrm{~cm}$ axilla & no data & retractor & $10 \mathrm{~mm}$ & no data & no data & no data \\
\hline Tamaki[23] & circumareolar incision & no data & retractor for face lifting & $4 \mathrm{~mm}$ & powerstar scissors & $\begin{array}{c}\text { retractor and powerstar } \\
\text { scissors }\end{array}$ & circumareolar incision \\
\hline Yamaguchi[10] & $\begin{array}{c}8 \mathrm{~cm} \text { incision IM crease } \\
\text { or axilla depending on } \\
\text { tumour location }\end{array}$ & no data & PDB balloon & opitiview, $12 \mathrm{~mm}$ & $\begin{array}{l}\text { using endoscope but no } \\
\text { specific details }\end{array}$ & $\begin{array}{l}\text { with or without PDB } \\
\text { balloon }\end{array}$ & $\begin{array}{c}\text { via axilla or IM crease } \\
\text { incision }\end{array}$ \\
\hline Yamashita[7] & $2.5 \mathrm{~cm}$ axilla & yes, lap protector & $\begin{array}{c}\text { sutures to elevate the } \\
\text { breast tissue }\end{array}$ & $5 \mathrm{~mm}$ & $\begin{array}{l}\text { tunnelling method using } \\
\text { endodissector }\end{array}$ & $\begin{array}{l}\text { ultraretractor vein } \\
\text { harvest }\end{array}$ & endocatch, via axilla \\
\hline Yamashita[20] & axilla & & no data & visiport, $10 \mathrm{~mm}$ & no data & no data & no data \\
\hline Yamashita[8] & $2.5 \mathrm{~cm}$ axilla & yes, lap protector & $\begin{array}{c}\text { sutures to elevate the } \\
\text { breast tissue }\end{array}$ & bladeless trocar, $5 \mathrm{~mm}$ & $\begin{array}{l}\text { tunnelling method using } \\
\text { endodissector, septa } \\
\text { divided with harmonic }\end{array}$ & $\begin{array}{l}\text { ultraretractor vein } \\
\text { harvest }\end{array}$ & endocatch, via axilla \\
\hline Yamashita[9] & $2.5 \mathrm{~cm}$ axilla & yes, lap protector & $\begin{array}{l}\text { skin pulled up with } \\
\text { muscle clasps }\end{array}$ & $10 \mathrm{~mm}$ & $\begin{array}{l}\text { tunnelling method using } \\
\text { endodissector, septa } \\
\text { divided with harmonic }\end{array}$ & $\begin{array}{l}\text { ultraretractor vein } \\
\text { harvest }\end{array}$ & no data \\
\hline
\end{tabular}

\section{$\underline{\text { Table } 1 \text { legend. }}$}

$\mathrm{AAL}=$ anterior axillary line, $\mathrm{MAL}=$ mid axillary line, $\mathrm{IM}=$ inframammary, $\mathrm{CO}_{2}=$ carbon dioxide 
Table 2 Summary table detailing study synopsis and demographic data for studies of endoscopic minimally invasive mastectomy (1/2)

\begin{tabular}{|c|c|c|c|c|c|c|c|c|c|c|c|c|c|c|c|}
\hline \multirow[t]{2}{*}{ Author } & \multirow[t]{2}{*}{$\begin{array}{l}\text { Study } \\
\text { type }\end{array}$} & \multirow{2}{*}{$\begin{array}{c}\text { Tumour } \\
\text { size } \\
\text { limit } \\
\text { (cm) for } \\
\text { ESM }\end{array}$} & \multirow[t]{2}{*}{$\begin{array}{c}\text { Full or } \\
\text { partial } \\
\text { ESM }\end{array}$} & \multicolumn{2}{|c|}{$\begin{array}{c}\text { Number of } \\
\text { patients }\end{array}$} & \multicolumn{2}{|c|}{$\begin{array}{l}\text { Av. tumour size cm } \\
\quad(\text { range or } \pm \mathrm{SD})\end{array}$} & \multicolumn{2}{|c|}{ Tumour staging } & \multicolumn{2}{|c|}{$\begin{array}{l}\text { Chemotherapy / } \\
\text { Radiotherapy / } \\
\text { Endocrine thx }\end{array}$} & \multicolumn{2}{|c|}{$\begin{array}{c}\text { Average operative } \\
\text { duration } \\
\text { in minutes (range or } \pm \\
\text { SD) }\end{array}$} & \multirow[t]{2}{*}{ Reconstruction } & \multirow[t]{2}{*}{ ALND } \\
\hline & & & & ESM & Open & ESM & Open & ESM & Open & ESM & Open & ESM & Open & & \\
\hline Tamaki[22] & series & $\leq 2.5$ & partial & 7 & - & $(0.7-2.5)$ & - & - & - & $\begin{array}{c}\text { DXT }(50 \mathrm{~Gy})= \\
\text { all patients }\end{array}$ & - & 387 (309-465) & - & $\begin{array}{l}\text { mammary gland } \\
\text { and fat flap }\end{array}$ & $\dagger$ \\
\hline Kitamura[11] & series & $\leq 5.5$ & lumpectomy & 6 & - & $\leq 5.5$ & - & benign & - & - & - & $200(150-360)$ & - & - & - \\
\hline Kitamura[12] & cohort & - & lumpectomy & 36 & - & $\begin{array}{c}3.6 \\
(2.5-11)\end{array}$ & - & benign & - & - & - & 147 & - & - & - \\
\hline Tamaki[23] & series & $<2$ & partial & 6 & - & $\begin{array}{c}1.6 \\
(1.3-2.2)\end{array}$ & - & & - & $\begin{array}{l}\text { DXT = all BCS } \\
\text { pts, boost DXT } \\
=1 \text { pt margin }+\end{array}$ & - & $241(190-315)$ & - & - & $\begin{array}{l}\dagger \text { or } \\
\text { SLNB }\end{array}$ \\
\hline Kitamura[19] & $\begin{array}{l}\text { non-rd } \\
\text { control } \\
\text { trial }\end{array}$ & - & full & 21 & 25 & $\begin{array}{c}2.1 \\
( \pm 1.2)\end{array}$ & $\begin{array}{l}2.1 \\
( \pm \\
1.0)\end{array}$ & $\begin{array}{l}\mathrm{I}=14 \\
\mathrm{II}=7\end{array}$ & $\begin{array}{l}\mathrm{I}=16 \\
\mathrm{II}=9\end{array}$ & $\begin{array}{l}\text { DXT for } \\
\text { margin+ } \\
=1(4.8 \%)\end{array}$ & $\begin{array}{c}\text { DXT } \\
\text { for } \\
\text { margin } \\
+=2 \\
(8.0 \%)\end{array}$ & $237 \pm 60$ & $176 \pm 32$ & $\begin{array}{l}\text { saline filled } \\
\text { prosthesis }\end{array}$ & $\dagger$ \\
\hline Owaki[14] & Series & 1.5 & quadrant & 6 & - & $0.6, \mathrm{ni}-2.7$ & - & - & - & - & - & $165(45-260)$ & - & mammary gland & $\begin{array}{c}\dagger \text { if } \\
\text { SLNB+ }\end{array}$ \\
\hline Lee[21] & Cohort & $<3$ & quadrant & 20 & - & $2.2(0.2-4.0)$ & - & $0=4, \mathrm{I}=8, \mathrm{II}=8$ & - & $\begin{array}{c}\text { DXT }=95 \%(1 \\
\text { required } \\
\text { salvage } \\
\text { surgery }), \\
\text { endothx }=\text { if } \\
\text { ER+/PR+ } \\
\text { adjv=5pts stage } \\
\text { Iia }\end{array}$ & - & $163(115-205)$ & - & - & $\begin{array}{c}\dagger \text { if } \\
\text { SLNB+ }\end{array}$ \\
\hline Yamashita[9] & non-rd & - & $\begin{array}{l}\text { partial }(2 / 3 \\
\max )\end{array}$ & 100 & 34 & $1.8(0.1-6.5)$ & $\begin{array}{l}1.7 \\
(1.5- \\
4.0)\end{array}$ & $\begin{array}{c}0=5, \\
\mathrm{I}=46, \mathrm{IIA}=21, \mathrm{IIB}=10\end{array}$ & $\begin{array}{c}0=1, \\
\mathrm{I}=15, \mathrm{IIA}=13, \mathrm{IIB} \\
=5\end{array}$ & no data & no data & $173 \pm 45$ & $\begin{array}{c}149 \pm \\
32\end{array}$ & $\begin{array}{c}\text { a. remnant } \\
\text { gland, b. lateral } \\
\text { thoracic fat, c. } \\
\text { mesh }\end{array}$ & $\ddagger$ \\
\hline Yamashita[20] & Cohort & - & full & 150 & - & $2.1(0.1-9.0)$ & - & - & - & $\begin{array}{c}\text { DXT=all pts, } \\
\text { endocrine and } \\
\text { adjv=guided by } \\
\text { St Gallen's rec }\end{array}$ & - & no data & - & (1) & $\begin{array}{c}\dagger \\
\mathrm{n}=41, \dagger \\
\mathrm{n}=74\end{array}$ \\
\hline Ito[24] & Cohort & $<\mathrm{T} 2$ & full & 33 & - & & - & - & - & $\begin{array}{c}\text { adjv }=6.1 \% \\
\text { endothx }=90.9 \% \\
\text {, DXT }=3.0 \%\end{array}$ & - & $\begin{array}{l}\sim 240 \text { (with } \\
\text { implant } \\
\text { reconstruction) }\end{array}$ & - & $\begin{array}{c}\text { mammary } \\
\text { prosthesis } \\
(\mathrm{n}=30)\end{array}$ & $\dagger$ \\
\hline Ho[18] & Series & $<3$ & full & 9 & - & no data & - & no data & - & $\begin{array}{l}\text { adjv and DXT } \\
=\text { 'given in } \\
\text { usual manner' }\end{array}$ & - & $234(195-275)$ & - & prosthesis & $24^{\dagger}$ \\
\hline
\end{tabular}




\begin{tabular}{|c|c|c|c|c|c|c|c|c|c|c|c|c|c|c|c|}
\hline \multirow[t]{2}{*}{ Author } & \multirow{2}{*}{$\begin{array}{l}\text { Study } \\
\text { type }\end{array}$} & \multirow{2}{*}{$\begin{array}{c}\text { Tumour } \\
\text { size limit } \\
\text { (cm) for } \\
\text { ESM }\end{array}$} & \multirow{2}{*}{$\begin{array}{c}\text { Full or } \\
\text { partial } \\
\text { ESM }\end{array}$} & \multicolumn{2}{|c|}{$\begin{array}{l}\text { Number of } \\
\text { patients }\end{array}$} & \multicolumn{2}{|c|}{$\begin{array}{l}\text { Av. tumour size cm } \\
\quad(\text { range or } \pm \mathrm{SD})\end{array}$} & \multicolumn{2}{|c|}{ Tumour staging } & \multicolumn{2}{|c|}{$\begin{array}{c}\text { Chemotherapy / Radiotherapy / } \\
\text { Endocrine thx }\end{array}$} & \multicolumn{2}{|c|}{$\begin{array}{c}\text { Average operative } \\
\text { duration } \\
\text { in minutes (range or } \pm \\
\text { SD) }\end{array}$} & \multirow[t]{2}{*}{ Reconstruction } & \multirow[t]{2}{*}{ ALND } \\
\hline & & & & ESM & Open & ESM & Open & ESM & Open & ESM & Open & ESM & Open & & \\
\hline Nakajima[15] & cohort & $\leq 5$ & $\begin{array}{l}\text { partial } \\
\text { (BCS) }\end{array}$ & 551 & - & $\begin{array}{l}\text { Tis }=2.5 \pm 1.9 \\
\mathrm{~T} 1=1.5 \pm 0.5 \\
\mathrm{~T} 2=3.6 \pm 0.7\end{array}$ & - & - & - & $\begin{array}{l}\text { DXT }(50 \mathrm{~Gy})=\text { all } \\
\text { boost }(10 \mathrm{~Gy})=\text { if } \\
\text { margin }+\end{array}$ & - & $\begin{array}{l}\text { Tis }=238 \pm 47 \\
\mathrm{~T} 1=223 \pm 39 \\
\mathrm{~T} 2=239 \pm 52\end{array}$ & - & $\begin{array}{l}\text { breast gland } \\
(\mathrm{n}=258), \mathrm{LTF} \\
(\mathrm{n}=107) \mathrm{LDMF} \\
(\mathrm{n}=186)\end{array}$ & $\begin{array}{c}\text { SLNB } \\
- \\
\dagger\end{array}$ \\
\hline Nakajima[16] & cohort & $\leq 5$ & $\begin{array}{l}\text { partial } \\
\text { (BCS) }\end{array}$ & 244 & - & $\begin{array}{c}\text { stage } \mathrm{I}= \\
1.6 \\
\text { stageII }=3.1\end{array}$ & - & $\begin{array}{c}\text { stage } \\
\mathrm{I}=94 \\
\text { stage } \\
\mathrm{II}=150\end{array}$ & - & $\begin{array}{c}\text { DXT }(50 \mathrm{~Gy})=\text { all, } \\
\text { boost }(10 \mathrm{~Gy})= \\
14.3 \% \text { for rmargin+ } \\
\text { adjv=stage specific }\end{array}$ & - & $\begin{array}{l}\text { stage } \mathrm{I}=177, \\
\text { stage II }=236\end{array}$ & & & \\
\hline Sakamoto[17] & retrosp & - & full & 87 & - & $2.1(0.1-5.6)$ & - & $\begin{array}{c}0 / 1=37 \\
\mathrm{II}=50 \\
\mathrm{IIIA}=2\end{array}$ & - & $\begin{array}{l}\text { adjv }=64 \%, \\
\text { DXT }=30 \%\end{array}$ & - & No data & - & prosthesis & $\begin{array}{c}\text { SLNB } \\
\dagger\end{array}$ \\
\hline Yamashita[8] & cohort & - & partial & 12 & - & $2.0 \pm 0.9$ & - & $<\mathrm{IIA}$ & - & $\begin{array}{c}\text { DXT=all pts with } \\
\text { cancer, endocrine } \\
\text { and adjv=guided by } \\
\text { St Gallen's rec }\end{array}$ & - & $208 \pm 44$ & - & $\begin{array}{l}\text { a.mammary } \\
\text { gland, b.lateral } \\
\text { thoracic fat, } \\
\text { c.mesh or cotton }\end{array}$ & $\dagger$ \\
\hline Yamaguchi[10] & series & - & full & 21 & - & no data & - & no data & - & no data & - & $\begin{array}{c}\text { adv skin } \\
\text { flap }=251 \pm 55 \\
\text { posterior } \\
\text { approach } \\
=216 \pm 55\end{array}$ & - & prosthesis & $\dagger$ \\
\hline Fan[13] & $\begin{array}{l}\text { pros } \\
\text { non-rd } \\
\text { control } \\
\text { trial }\end{array}$ & $<3$ & full & 43 & 54 & $2.7 \pm 0.9$ & $2.6 \pm 0.9$ & $\begin{array}{l}\mathrm{I}=, 15 \\
\mathrm{II}=22 \\
\mathrm{IIIA}=6\end{array}$ & $\begin{array}{l}\mathrm{I}=, 22 \\
\mathrm{II}=27 \\
\mathrm{IIIA}=5\end{array}$ & $\begin{array}{c}\text { cycles of } \\
\text { neoadjv }=2.1 \pm 1.1 \\
\text { adjv=all } \\
\text { DXT }=\text { not routine, } \\
\text { Endthx=if ER/PR+ }\end{array}$ & $\begin{array}{c}\text { cycles of } \\
\text { neoadjv }=1.1 \pm 1.1, \\
\text { adjuv=all } \\
\text { DXT }- \text { routine, } \\
\text { Endthx=if } \\
\text { ER/PR+ }\end{array}$ & $168 \pm 32$ & $139 \pm 37$ & prosthesis & $\dagger$ \\
\hline
\end{tabular}

\section{Legend for Table 2.}

SLNB = sentinel lymph node biopsy, ALND = axillary lymph node dissection, NAC $=$ nipple areola complex. $\dagger=$ axillary staging $/$ clearance conducted simultaneously as a open procedure, $\$=$ axillary staging / clearance conducted simultaneously but performed endoscopically or with endoscopic-assistance, DXT=radiotherapy, Neoadjv=neoadjuvant chemotherapy, Adjx= adjuvant chemotherapy, Endthx=Endocrine therapy. 
Table 3 Summary table comparing post-operative complications following endoscopic minimally invasive mastectomy: (1/2)

\begin{tabular}{|c|c|c|c|c|c|c|c|c|c|c|c|c|c|c|}
\hline \multirow[t]{2}{*}{ Author (year) } & \multicolumn{2}{|c|}{$\begin{array}{l}\text { Intra-operative blood loss } \\
\qquad(\mathrm{ml} / \mathrm{g})\end{array}$} & \multicolumn{2}{|c|}{$\begin{array}{c}\text { Post-operative drainage } \\
\text { volume (ml) }\end{array}$} & \multicolumn{2}{|c|}{$\begin{array}{l}\text { Post-operative } \\
\text { drainage (days) }\end{array}$} & \multicolumn{2}{|c|}{$\begin{array}{c}\text { Skin flap necrosis, burns, } \\
\text { prosthesis } \mathbf{C x}\end{array}$} & \multicolumn{2}{|c|}{$\begin{array}{c}\text { Infection rates } \\
(\%)\end{array}$} & \multicolumn{2}{|c|}{$\begin{array}{l}\text { Haemorrhage / } \\
\text { Haematoma (\%) }\end{array}$} & \multicolumn{2}{|c|}{ Cosmetic Outcomes } \\
\hline & ESM & Open & ESM & Open & ESM & Open & ESM & Open & ESM & Open & ESM & Open & ESM & Open \\
\hline Tamaki[22] & $486(310-670) \mathrm{ml}$ & - & no data & - & no data & - & 2 burns & - & no data & - & no data & - & 7/7 satisfied & - \\
\hline Kitamura[11] & $<10 \mathrm{~g}$ & - & no data & - & no data & - & 1 burn, $1 \mathrm{SCE}$ & - & 0 & - & 0 & - & no data & - \\
\hline Kitamura[12] & $19 \pm 7 \mathrm{ml}$ & - & no data & - & no data & - & 1 burn, $1 \mathrm{SCE}$ & - & 0 & - & 0 & - & 36/36 satisfied & - \\
\hline Tamaki[23] & $192(60-290) \mathrm{ml}$ & - & no data & - & no data & - & 0 & - & 0 & - & 0 & - & 6/6 satisfied & - \\
\hline Kitamura[19] & $356 \pm 286 \mathrm{~g}$ & $189 \pm 72 \mathrm{~g}$ & no data & no data & no data & no data & $\begin{array}{c}3 \text { prosthesis } \\
(12 \%)\end{array}$ & $\begin{array}{c}1 \text { prosthesis } \\
\text { (4.8\%) }\end{array}$ & 0 & 0 & 0 & 0 & $\begin{array}{c}\text { Excellent }=85 \% \\
\text { Good= }=4.8 \% \\
\text { Fair }=4.8 \% \\
\text { Poor }=4.8 \%\end{array}$ & $\begin{array}{c}\text { Excellent }=60 \% \\
\text { Good=16\% } \\
\text { Fair }=12 \% \\
\text { Poor }=12 \%\end{array}$ \\
\hline Nakajima[25] & no data & - & no data & - & no data & - & ? supf burns & - & 0 & - & 0 & - & $17 / 17=\operatorname{good}$ & - \\
\hline Owaki[14] & $150 \pm 96.9 \mathrm{ml}$ & - & no data & - & no data & - & no data & - & no data & - & no data & - & $6 / 6$ satisfied & - \\
\hline Lee[21] & $184 \pm 130 \mathrm{ml}$ & - & no data & - & no data & - & 0 & - & 0 & - & 0 & - & $\begin{array}{c}89.5 \% \text { satisfied } \\
\text { Excellent }=36.9 \\
\text { Good }=52.6 \\
\text { Fair }=10.5 \\
\text { Poor }=0\end{array}$ & - \\
\hline Yamashita[9] & $174 \pm 118 \mathrm{~g}$ & $147 \pm 118 \mathrm{~g}$ & $421 \pm 263$ & $259 \pm 165$ & $4.06 \pm 2.0$ & $3.25 \pm 1.19$ & 4 burns & no data & 0 & no data & $7 / 2$ & no data & $\begin{array}{c}\text { Av. ABNSW = } \\
13.5,90 \% \\
\text { good or excel }\end{array}$ & no data \\
\hline Yamashita[20] & no data & - & no data & - & no data & - & no data & - & no data & - & no data & - & no data & - \\
\hline Ito[24] & no data & - & no data & - & no data & - & nacnec 3(9.1) & - & $3(9.1)$ & - & & - & no data & - \\
\hline Yamashita[7] & no data & - & no data & - & no data & - & 0 & - & 0 & - & 0 & - & $\begin{array}{c}\text { ABNSW }= \\
14 \text { or } 15\end{array}$ & - \\
\hline
\end{tabular}


$\underline{\text { Table } 3 \text { continued }(2 / 2)}$

\begin{tabular}{|c|c|c|c|c|c|c|c|c|c|c|c|c|c|c|}
\hline \multirow[t]{2}{*}{ Author (year) } & \multicolumn{2}{|c|}{$\begin{array}{c}\text { Intra-operative blood loss } \\
\qquad(\mathrm{ml} / \mathrm{g})\end{array}$} & \multicolumn{2}{|c|}{$\begin{array}{c}\text { Post-operative } \\
\text { drainage volume (ml) }\end{array}$} & \multicolumn{2}{|c|}{$\begin{array}{l}\text { Post-operative } \\
\text { drainage (days) }\end{array}$} & \multicolumn{2}{|c|}{$\begin{array}{c}\text { Skin flap necrosis, burn, } \\
\text { prosthesis } \mathrm{Cx}(\%)\end{array}$} & \multicolumn{2}{|c|}{$\begin{array}{c}\text { Infection rates } \\
(\%)\end{array}$} & \multicolumn{2}{|c|}{$\begin{array}{c}\text { Haematoma } \\
(\%)\end{array}$} & \multicolumn{2}{|c|}{ Cosmetic Outcomes } \\
\hline & ESM & Open & ESM & Open & ESM & Open & ESM & Open & ESM & Open & ESM & Open & ESM & Open \\
\hline $\mathrm{Ho}[18]$ & $135 \mathrm{ml}$ & - & no data & - & no data & - & 2 skin bruises & - & $\begin{array}{l}\text { no } \\
\text { data }\end{array}$ & - & $\begin{array}{l}\text { no } \\
\text { data }\end{array}$ & - & $\begin{array}{c}\text { av. self assessment } \\
\text { satisfaction index }=8\end{array}$ & - \\
\hline Nakajima[15] & $\begin{array}{c}\text { Tis }=116 \pm 23 \mathrm{~g} \\
\mathrm{~T} 1=107 \pm 27 \mathrm{~g} \\
\mathrm{~T} 2=141 \pm 34 \mathrm{~g} \\
\text { Total }=127 \pm 49 \mathrm{~g}\end{array}$ & - & no data & - & no data & - & $\begin{array}{c}\text { skin }=22(4.0) \\
\text { muscle }=17(3.1)\end{array}$ & - & $\begin{array}{l}\text { no } \\
\text { data }\end{array}$ & - & $\begin{array}{l}\text { no } \\
\text { data }\end{array}$ & - & $\begin{array}{c}\text { overall } \\
\text { good }=76.1 \% \\
\text { fair }=13.7 \\
\text { poor }=10 \%\end{array}$ & - \\
\hline Nakajima[16] & $\begin{array}{l}\text { Stage }=125 \mathrm{~g} \\
\text { StageII }=143 \mathrm{~g}\end{array}$ & - & no data & - & no data & - & $\begin{array}{c}\text { skin }=9(3.7) \\
\text { fat }=7(2.9) \\
\text { muscle }=1(0.4)\end{array}$ & - & $2(0.8)$ & - & $\begin{array}{c}4 \\
(1.6)\end{array}$ & - & $\begin{array}{c}\text { overall } \\
\text { good }=72.3 \% \\
\text { fair }=11.2 \% \\
\text { poor16.5 }\end{array}$ & - \\
\hline Sakamoto[17] & No data & - & no data & - & no data & - & $\begin{array}{c}\text { skin=3(3.4) } \\
\text { nacnec }=16(18)\end{array}$ & no data & $1(1.1)$ & - & $\begin{array}{l}\text { no } \\
\text { data }\end{array}$ & - & no data & - \\
\hline Yamashita[8] & $149 \pm 118 \mathrm{~g}$ & - & no data & - & no data & - & no data & - & $\begin{array}{l}\text { no } \\
\text { data }\end{array}$ & - & $\begin{array}{l}\text { no } \\
\text { data }\end{array}$ & - & $\begin{array}{l}\text { ABNSW= } \\
14 \text { or } 15\end{array}$ & - \\
\hline Fan[13] & $115 \pm 44 \mathrm{ml}$ & $102 \pm 48 \mathrm{ml}$ & $150 \pm 63$ & $160 \pm 69$ & $6.7 \pm 2.1$ & $6.3 \pm 2.1$ & $\begin{array}{c}\text { nacnec }=2 \\
\text { skin blisters }=3 \\
\text { overall=5/43 (11.6) }\end{array}$ & $\begin{array}{c}\text { hydrops } \\
(11.6) \\
\text { Overall=6/54 } \\
(11.6) \\
\end{array}$ & $\begin{array}{l}\text { no } \\
\text { data }\end{array}$ & $\begin{array}{l}\text { no } \\
\text { data }\end{array}$ & $\begin{array}{l}\text { no } \\
\text { data }\end{array}$ & $\begin{array}{c}\text { no } \\
\text { data }\end{array}$ & $\begin{array}{c}\text { excellent }=20.9 \% \\
\text { good }=37.2 \% \\
\text { fair }=30.2 \% \\
\text { poor }=11.6 \%\end{array}$ & $\begin{array}{l}\text { overall } \\
92.6 \% \\
\text { satisfied }\end{array}$ \\
\hline Yamaguchi[10] & $238 \pm 156 \mathrm{ml}$ & - & no data & - & no data & - & no data & - & $\begin{array}{l}\text { no } \\
\text { data }\end{array}$ & - & $\begin{array}{l}\text { no } \\
\text { data }\end{array}$ & - & no data & - \\
\hline
\end{tabular}

\section{Legend for Table 3}

$\mathrm{ESM}=$ endoscopic mastectomy, $\mathrm{Cx}=$ complications, $\mathrm{Nacnec}=$ nipple areolar complex necrosis, supf $=$ superficial, $\mathrm{SCE}=$ subcutaneous emphysema 
$\underline{\text { Table } 4 \text { Summary table comparing oncological outcomes following endoscopic mastectomy }(1 / 2)}$

\begin{tabular}{|c|c|c|c|c|c|c|c|c|c|c|}
\hline \multirow{2}{*}{ Author (year) } & \multicolumn{2}{|c|}{ Average follow up (months) } & \multicolumn{2}{|c|}{$\begin{array}{c}\text { Margin Involvement } \\
\qquad n(\%)\end{array}$} & \multicolumn{2}{|c|}{$\begin{array}{c}\text { Local Recurrence } \\
\qquad n(\%)\end{array}$} & \multicolumn{2}{|c|}{$\begin{array}{c}\text { Metastatic Disease } \\
n(\%)\end{array}$} & \multicolumn{2}{|c|}{$\begin{array}{c}\text { Overall Survival } \\
n(\%)\end{array}$} \\
\hline & ESM & Open & ESM & Open & ESM & Open & ESM & Open & ESM & Open \\
\hline Tamaki[22] & 22 & - & no data & - & no data & - & no data & - & no data & - \\
\hline Kitamura[11] & no data & - & no data & - & no data & - & no data & - & no data & - \\
\hline Kitamura[12] & 16.7 & - & no data & - & 0 & - & no data & - & no data & - \\
\hline Tamaki[23] & no data & - & $1(16.6)$ & - & 0 & - & no data & - & no data & - \\
\hline Kitamura[19] & $19.2 \pm 9.8$ & $19.2 \pm 9.8$ & $1(4.8)$ & $2(8.0)$ & 0 & 0 & 0 & 0 & $20 / 20(100)$ & $24 / 24(100)$ \\
\hline Nakajima[25] & no data & - & no data & - & no data & - & $\begin{aligned} \text { ALN- } & =3(17.6) \\
\text { ALN }+ & =14(82.4)\end{aligned}$ & - & no data & - \\
\hline Owaki[14] & no data & - & no data & - & no data & - & $\mathrm{ALN}-=6(100)$ & - & no data & - \\
\hline Lee[21] & no data & - & $\begin{array}{c}1(5) \text { margint+ } \\
1 \text { (5) persistent MCC }\end{array}$ & - & no data & - & $\begin{array}{l}\mathrm{ALN}-=18(90) \\
\mathrm{ALN}+=2(10)\end{array}$ & - & no data & - \\
\hline Yamashita[9] & 25 & no data & $3(3)$ & no data & 0 & no data & excl criteria & excl criteria & no data & no data \\
\hline Yamashita[20] & no data & - & no data & - & no data & - & $\begin{array}{c}\text { SLNB- }=88 / 115 \\
\text { SLNB+= }=22 / 115\end{array}$ & - & no data & - \\
\hline Yamaguchi[10] & no data & - & no data & - & no data & - & no data & - & no data & - \\
\hline
\end{tabular}




\section{Table 4 continued (2/2)}

\begin{tabular}{|c|c|c|c|c|c|c|c|c|c|c|}
\hline \multirow{2}{*}{ Author (year) } & \multicolumn{2}{|c|}{ Average follow up (months) } & \multicolumn{2}{|l|}{$\begin{array}{c}\text { Margin Involvement } \\
n(\%)\end{array}$} & \multicolumn{2}{|c|}{$\begin{array}{c}\text { Local Recurrence } \\
n(\%)\end{array}$} & \multicolumn{2}{|c|}{$\begin{array}{c}\text { Metastatic Disease } \\
n(\%)\end{array}$} & \multicolumn{2}{|c|}{$\begin{array}{c}\text { Overall Survival (OS) } \\
(\%)\end{array}$} \\
\hline & ESM & Open & ESM & Open & ESM & Open & ESM & Open & ESM & Open \\
\hline Ito[24] & $51.2(16-86)$ & - & $8(24.3)$ - required NAC excision & - & 0 & - & $\begin{array}{l}\text { ALN- }=30(90) \\
\text { ALN+ }=3(9.1)\end{array}$ & - & $33 / 33(100)$ & - \\
\hline Yamashita[7] & 12 & - & 0 & - & 0 & - & no data & - & $20 / 20(100)$ & - \\
\hline Но[18] & no data & - & 0 & - & no data & - & no data & - & no data & - \\
\hline Nakajima[15] & 38.4 & - & $\begin{array}{c}\text { Tis }=16(34.0) \\
\text { T1 }=35(18.4) \\
\text { T2 }=62(19.5) \\
\text { Total }=113(20.5)\end{array}$ & - & $\begin{array}{c}\text { Tis }=0 \\
\mathrm{~T} 1=7(3.7) \\
\mathrm{T} 2=16(5.1) \\
\text { Total }=23(4.2)\end{array}$ & - & $\begin{array}{c}\text { ALN }+ \\
\text { Tis }=2(4.3) \\
\text { T1 }=24(12.6) \\
\text { T2 }=97(30.9) \\
\text { Total }=123(22.3) \\
\text { F/U distant Mets } \\
\text { Tis }=0 \\
\text { T1 }=7(3.7) \\
\text { T2 }=18(5.7) \\
\text { Total }=25(4.5)\end{array}$ & - & $\begin{array}{l}\text { Tis }=(100) \\
\text { T1 }=(97.3) \\
\text { T2 }=(95.7)\end{array}$ & - \\
\hline Nakajima[16] & 65.3 & - & $\begin{array}{l}\text { Stage I }=12(12.8) \\
\text { StageII }=23(15.3)\end{array}$ & - & $\begin{array}{l}\text { Stage I }=5(5.3) \\
\text { StageII }=8(5.3)\end{array}$ & - & $\begin{array}{c}\text { ALN }+ \\
\text { Stage } \mathrm{I}=7(7.4) \\
\text { Stage II }=41(27.3) \\
\text { F/U distant Mets } \\
\text { Stage I }=6(6.4) \\
\text { Stage II }=15(10)\end{array}$ & - & $\begin{array}{l}\text { Stage I }=(95.7) \\
\text { Stage II }=(96.9)\end{array}$ & - \\
\hline Yamashita[8] & no data & - & no data & - & no data & - & no data & - & no data & - \\
\hline Sakamoto[17] & $52(16-80)$ & $=$ & 0 & - & 0 & - & $\begin{array}{c}\quad \underline{\text { ALN }+} \\
<3 \text { nodes }=23(26) \\
>4 \text { nodes }=13(15) \\
\frac{\text { F/U distant Mets }}{9(10)}\end{array}$ & - & no data & - \\
\hline
\end{tabular}




\section{Legend for Table 4}

$\mathrm{ESM}=$ endoscopic mastectomy, $\mathrm{NAC}=$ nipple areolar complex, $\mathrm{ALN}=$ axillary lymph node, $\mathrm{MCC}=$ micro calcification, $\mathrm{SLNB}=$ sentinel lymph node biopsy, excl = exclusion, $\mathrm{F} / \mathrm{U}=$ follow up. 
Table 5. Oncological outcomes following open subcutaneous mastectomy and nipple sparing mastectomy in studies with more than 100 patients

\begin{tabular}{|c|c|c|c|c|}
\hline Author & Number of Patients & $\begin{array}{l}\text { Type of Surgery } \\
\text { (SSM or NSM) }\end{array}$ & $\begin{array}{c}\text { Positive Histological } \\
\text { Margin (\%) }\end{array}$ & Local Recurrence Rate (\%) \\
\hline Reefy[30] & 137 & SSM & 0.72 & 0 \\
\hline Сao [31] & 168 & SSM & 38 & - \\
\hline Medina-Franco[32] & 176 & SSM & - & 4.5 \\
\hline Carlson[33] & 539 & SSM & - & 5.5 \\
\hline$*$ Gerber [34] & 48 & SSM & - & 10.4 \\
\hline Kroll [35] & 118 & SSM & - & 7.0 \\
\hline Vaughan [36] & 210 & SSM & $\begin{array}{c}13 \% \text { in patients without } \mathrm{LR}, \\
27 \% \text { in patients with LR }\end{array}$ & 5.3 \\
\hline Spiegel [37] & 177 & SSM & - & 5.6 \\
\hline Greenway [38] & 225 & SSM & - & 1.7 \\
\hline Meretoja [39] & 146 & SSM & - & 2.7 \\
\hline Yi [26] & 799 & SSM & 0.3 & 0.6 \\
\hline $\operatorname{Kim}[40]$ & 368 & SSM & - & 0.8 \\
\hline Cheung [41] & 101 & SSM & $1.9 \%$ DCIS in NAC skin & 16.0 \\
\hline Petit [42] & 679 & NSM & $\begin{array}{c}\text { In pts with negative NAC } \\
\text { cores }=2 \% \text { invasive, } 8.8 \% \text { DCIS }\end{array}$ & $0.9 /$ year \\
\hline *Gerber [34] & 60 & NSM & - & 10.0 \\
\hline Crowe [43] & 110 & NSM & - & 6.7 \\
\hline $\operatorname{Kim}[40]$ & 152 & NSM & - & 2.0 \\
\hline Benediktsson [44] & 216 & NSM & - & 24.0 \\
\hline
\end{tabular}

Table 5 legend. SSM = skin sparing mastectomy, NSM = nipple areolar complex sparing mastectomy, DCIS = ductal carcinoma insitu, NAC = nipple areolar complex, LR = local recurrence, * included over 100 patients in the SSM / NSM arm with set criteria to determine which procedure was performed. 


\section{Figures and Figure Legends}

\section{Figure 1}
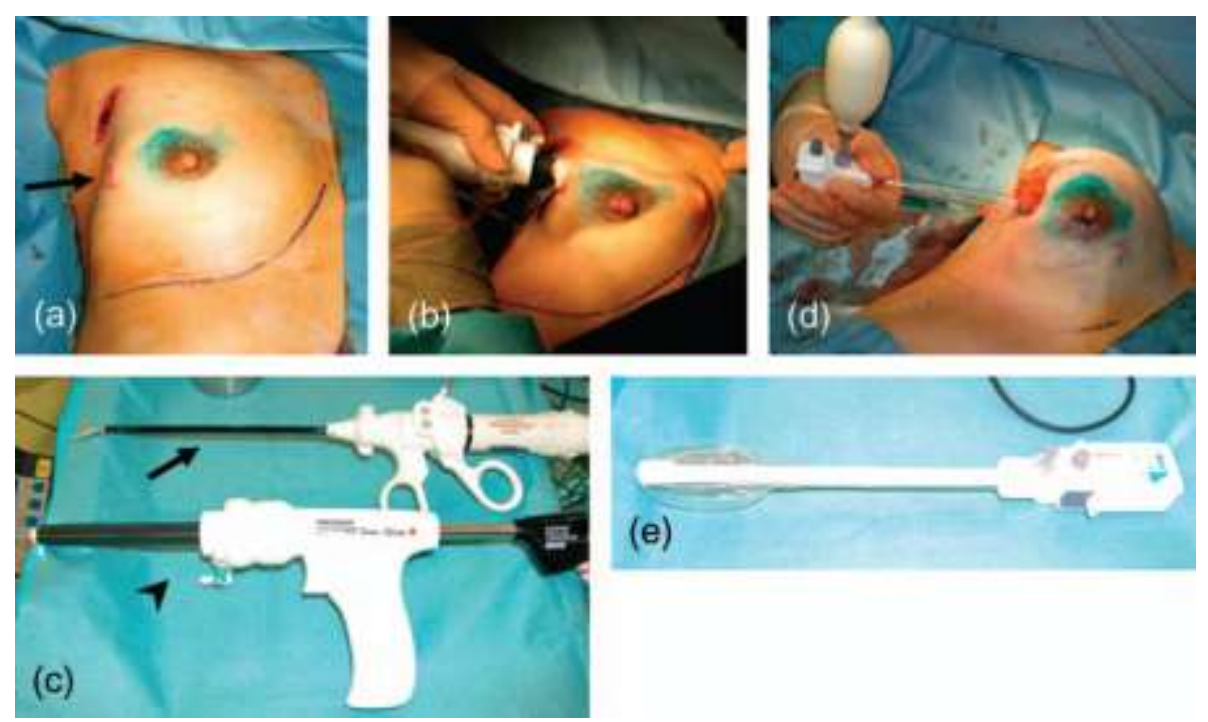

Breast and sentinel lymph node biopsy incision (a), visualisation trocar is inserted through the axillary incision which had been used to conduct SLNB, and a skin flap is created (b), harmonic scalpel (arrow) and visualised trocar (arrowhead) (c), using a dissection balloon the breast tissue is dissected off the pectoralis fascia (d), the dissection balloon (e). Reprinted with kind permission, Wiley and Sons. Original publication: Ito et al, ANZ J Surg 2008; 78:894-898 [24]. 


\section{Figure 2}

(i)

(ii)
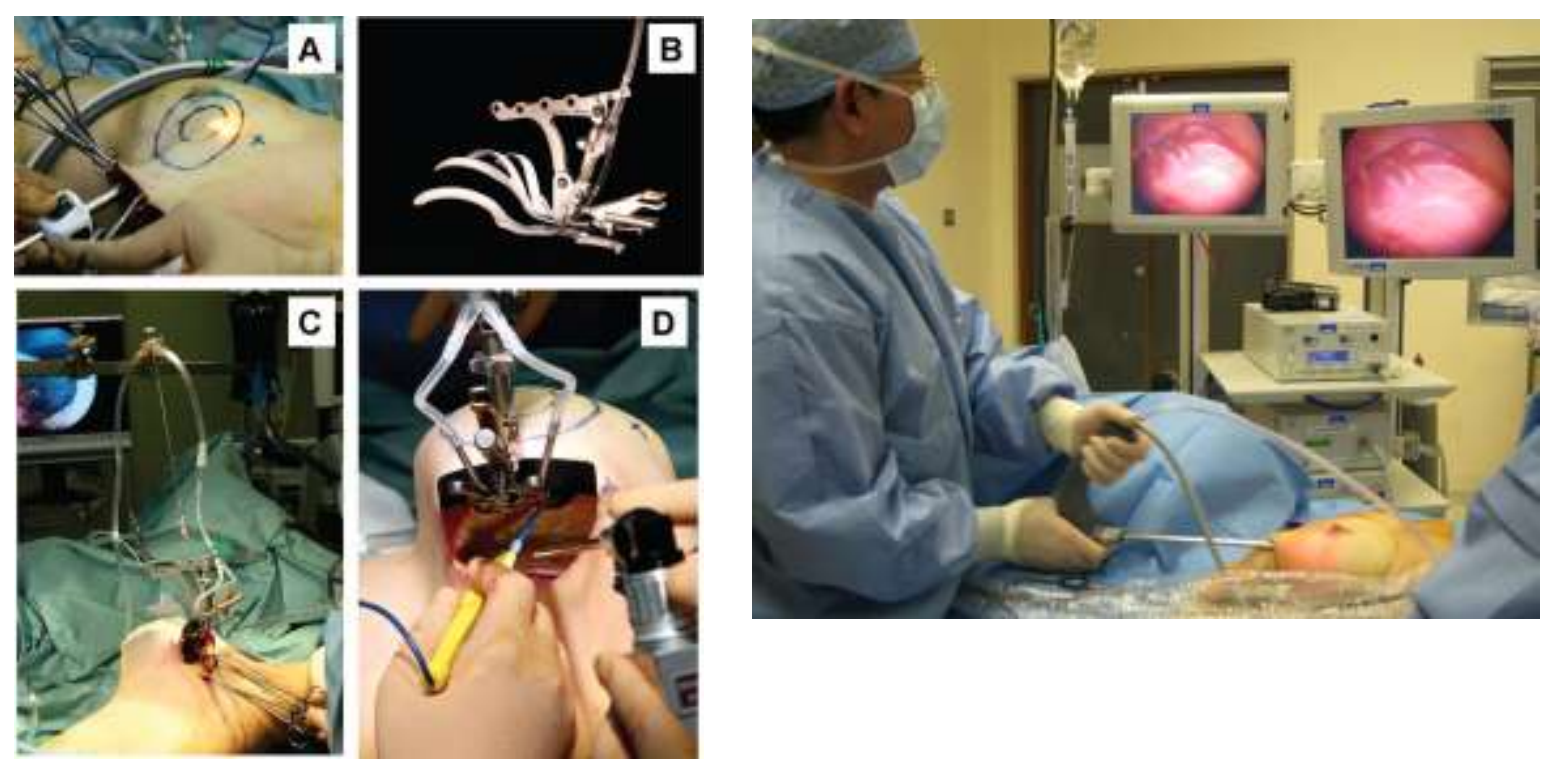

(i) Subcutaneous tunnelling method and lifting method. (A) Separation between breast gland and skin under video guidance using the subcutaneous tunnelling method, (B) HIROTECH retractor, (C) separation between breast gland and skin under video guidance, (D) separation between breast gland and pectoralis major muscle under video guidance from the mid axillary incision using the lifting method. Reprinted with kind permission from Lippincott, Williams and Wilkins. Original publication: Nakajima et al Ann Surg 2009; 249(1):91-96 [15].

(ii) Endoscopic breast dissection being conducted using the CLEARGLIDE precision bipolar device (Cardiovations, Ethicon). 


\section{Figure 3}

Systematic literature search strategy.

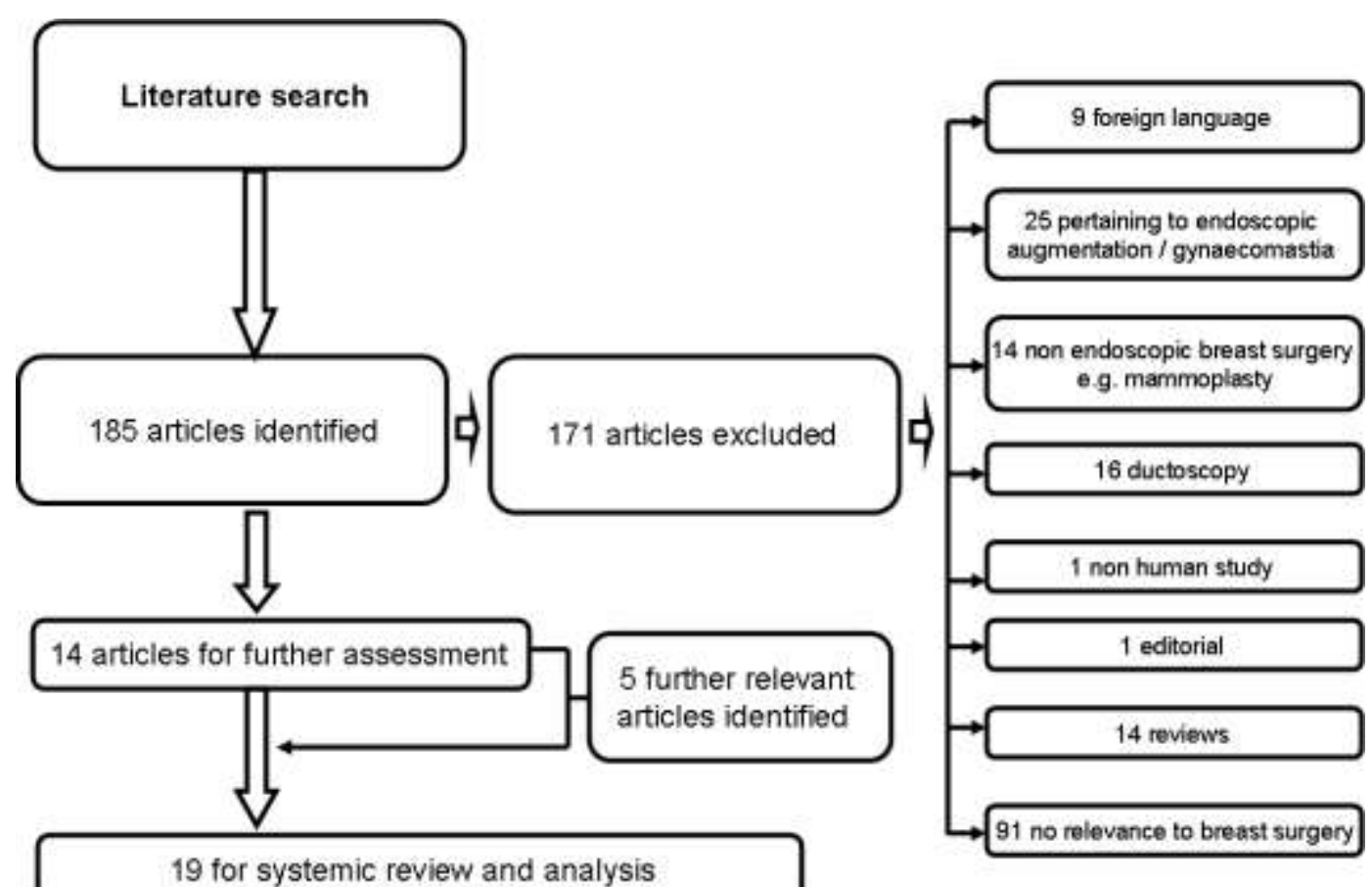




\section{Figure 4}

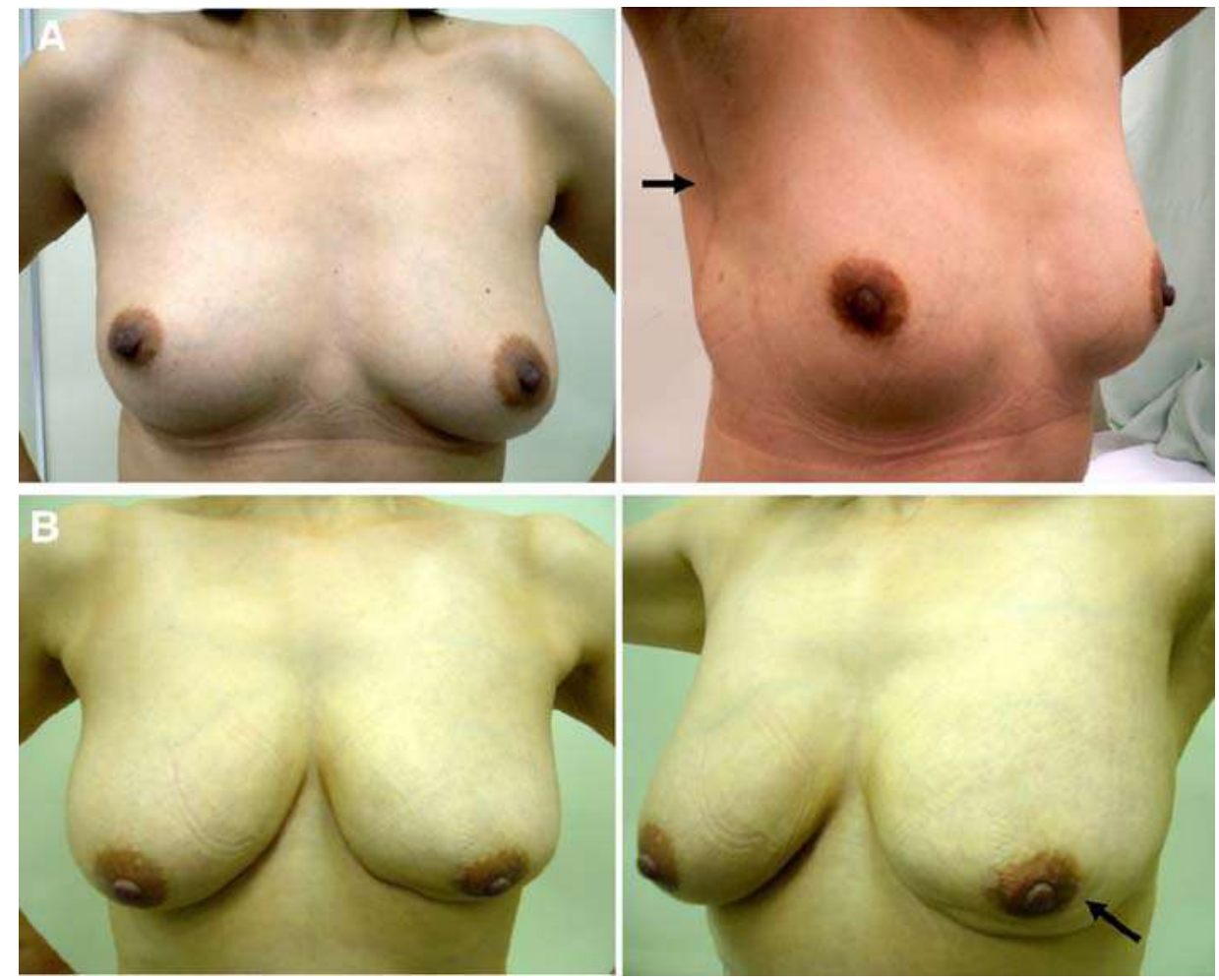

Cosmetic outcomes following endoscopic breast cancer resection and reconstruction. (A) 41-year-old woman with a right sided breast cancer (diameter $2.9 \mathrm{~cm}$ ) in the upper outer area who underwent video-assisted BCS and reconstruction with latissimus dorsi muscle flap via a midaxillary line incision. Skin incision was invisible from the frontal view as of 3 years after operation. (B) A 48-year-old woman with left breast cancer (diameter 2.2 $\mathrm{cm}$ ) in the lower-outer area who underwent video-assisted breast-conserving surgery and reconstruction with mobilization of the remnant breast gland and fat tissue via periareolar incision. Skin incision was inconspicuous as of 2 years after operation. Arrows show the skin incisions. Republished with kind permission from Springer. Original publication: Nakajima et al Ann Surg Onc 2009 16:1982-1989[16]. 


\section{$\underline{\text { References }}$}

1. Ingram D (2008). Is it time for breast cancer surgeons to embrace endoscopicassisted mastectomy? ANZ J Surg 78(10):837-8.

2. Halstead W (1894). The results of operations for the cure of cancer of the breast performed at the Johns Hopkins Hospital from June 1889 to January 1894. Arch Surg 20: 497-555.

3. Patey DH, Dyson WH (1948). The prognosis of carcinoma of the breast in relation to the type of operation performed. Br J Cancer 2(1)7-13

4. Newman LA, Kuerer HM, Hunt KK, Kroll SS, Ames FC, Ross MI, et al (1998). Presentation, treatment, and outcome of local recurrence after skin-sparing mastectomy and immediate breast reconstruction. Ann Surg Oncol 5(7):620-6..

5. Keshtgar MR, Fukuma E (2009). Endoscopic mastectomy: what does the future hold? Womens Health 5(2):107-9.

6. Tamaki Y, Tsukamoto F, Miyoshi Y, Tanji Y, Taguchi T, Noguchi S (2002). Overview: video-assisted breast surgery. Biomed Pharmacother 56 Suppl 1:187s$191 \mathrm{s.}$

7. Yamashita K, Shimizu K (2008). Transaxillary retromammary route approach of video-assisted breast surgery enables the inner-side breast cancer to be resected for breast conserving surgery. Am J Surg 196(4):578-81.

8. Yamashita K, Shimizu K (2008). Trans-axillary retro-mammary gland route approach of video-assisted breast surgery can perform breast conserving surgery for cancers even in inner side of the breast. Chin Med J (Engl) 121(20):1960-

9. Yamashita K, Shimizu K (2006). Endoscopic video-assisted breast surgery: procedures and short-term results. J Nippon Med Sch 73(4):193-202.

10. Yamaguchi S, Asao T, Uchida N, Yanagita Y, Saito K, Yamaki S, et al (2008). Endoscopy-assisted subcutaneous mastectomy and immediate breast reconstruction for breast cancer: advantage of the posterior approach. Int Surg 93(2):99-102.

11. Kitamura K, Hashizume M, Sugimachi K, Kataoka A, Ohno S, Kuwano H, et al (1998). Early experience of endoscopic extirpation of benign breast tumors via an extra-mammary incision. Am J Surg 176(3):235-8.

12. Kitamura K, Inoue H, Ishida M, Kinoshita J, Hashizume M, Sugimachi K (2001). Endoscopic extirpation of benign breast tumors using an extramammary approach. Am J Surg 181(3):211-4.

13. Fan LJ, Jiang J, Yang XH, Zhang Y, Li XG, Chen XC, et al (2009). A prospective study comparing endoscopic subcutaneous mastectomy plus immediate reconstruction with implants and breast conserving surgery for breast cancer. Chin Med J (Engl) 122(24):2945-50. 
14. Owaki T, Yoshinaka H, Ehi K, Kijima Y, Uenosono Y, Shirao K, et al (2005).

Endoscopic quadrantectomy for breast cancer with sentinel lymph node navigation via a small axillary incision. Breast 14(1):57-60..

15 Nakajima H, Fujiwara I, Mizuta N, Sakaguchi K, Hachimine Y (2009). Videoassisted skin-sparing breast-conserving surgery for breast cancer and immediate reconstruction with autologous tissue. Ann Surg 249(1):91-6.

16. Nakajima H, Fujiwara I, Mizuta N, Sakaguchi K, Hachimine Y, Magae J (2009). Video-assisted skin-sparing breast-conserving surgery for breast cancer and immediate reconstruction with autologous tissue: clinical outcomes. Ann Surg Oncol 16(7):1982-9.

17. Sakamoto N, Fukuma E, Higa K, Ozaki S, Sakamoto M, Abe S, et al(2009). Early results of an endoscopic nipple-sparing mastectomy for breast cancer. Ann Surg Oncol 16(12):3406-13.

18. Ho WS, Ying SY, Chan AC (2002). Endoscopic-assisted subcutaneous mastectomy and axillary dissection with immediate mammary prosthesis reconstruction for early breast cancer . Surg Endosc 16(2):302-6.

19. Kitamura K, Ishida M, Inoue H, Kinoshita J, Hashizume M, Sugimachi K (2002). Early results of an endoscope-assisted subcutaneous mastectomy and reconstruction for breast cancer. Surgery 131(1 Suppl):S324-9.

20 Yamashita K, Shimizu K (2008). Video-assisted breast surgery and sentinel lymph node biopsy guided by three-dimensional computed tomographic lymphography. Surg Endosc ;22(2):392-7.

21. Lee EK, Kook SH, Park YL, Bae WG (2006). Endoscopy-assisted breast conserving surgery for early breast cancer. World J Surg 30(6):957-64.

22. Tamaki Y, Nakano Y, Sekimoto M, Sakita I, Tomita N, Ohue M, et al (1998). Transaxillary endoscopic partial mastectomy for comparatively early-stage breast cancer. An early experience Surg Laparosc Endosc 8(4):308-12.

23. Tamaki Y, Sakita I, Miyoshi Y, Sekimoto M, Takiguchi S, Monden M, et al. Transareolar endoscopy-assisted partial mastectomy: a preliminary report of six cases (2001). Surg Laparosc Endosc Percutan Tech 11(6):356-62.

24. Ito K, Kanai T, Gomi K, Watanabe T, Ito T, Komatsu A, et al (2008). Endoscopicassisted skin-sparing mastectomy combined with sentinel node biopsy. ANZ J Surg 78(10):894-8.

25. Nakajima H, Sakaguchi K, Mizuta N, Hachimine T, Ohe S, Sawai K (2002). Video-assisted total glandectomy and immediate reconstruction for breast cancer. Biomed Pharmacother 56 Suppl 1:205s-208s.

26. Yi M, Kronowitz S J, Meric-Bernstam F, Feig BW, Symmans WF, Lucci A, ,et al (2010). Local, regional, and systemic recurrence rates in patients undergoing skinsparing mastectomy compared with conventional mastectomy. Cancer. 
27. Curet MJ (2004) Port site metastases. Am J Surg 187(6): 705-12.

28. Vaidya JS, Joseph DJ, Tobias JS, Bulsara M, Wenz F, Saunders C, et al (2010 In Press). Targeted intraoperative radiotherapy versus whole breast radiotherapy for breast cancer (TARGIT-A trial): an international, prospective, randomised noninferiority phase 3 trial. Lancet.

29. Wu F, Wang ZB, Cao YD, Chen WZ, Bai J, Zou JZ, et al (2003). A randomised clinical trial of high-intensity focused ultrasound ablation for the treatment of patients with localised breast cancer. Br J Cancer 89(12):2227-33.

30. Reefy S, Patani N, Anderson A, Burgoyne G, Osman H, Mokbe K, et al (2010). Oncological outcome and patient satisfaction with skin-sparing mastectomy and immediate breast reconstruction: a prospective observational study. BMC Cancer 10: 171 .

31. Cao D, Tsangaris TN, Kouprina N, Wu LS, Balch CM, Vang R, et al (2008). The superficial margin of the skin-sparing mastectomy for breast carcinoma: factors predicting involvement and efficacy of additional margin sampling. Ann Surg Oncol 15(5): 1330-40.

32. Medina-Franco H, Vasconez LO, Fix RJ, Heslin MJ, Beenken SW, Bland KI, et al (2002) Factors associated with local recurrence after skin-sparing mastectomy and immediate breast reconstruction for invasive breast cancer. Ann Surg 235(6): 8149.

33. Carlson GW, Styblo TM, Lyles RH, Jones G, Murray DR, Staley CA, et al (2003). The use of skin sparing mastectomy in the treatment of breast cancer: The Emory experience. Surg Oncol 12(4):265-9.

34. Gerber B, Krause A, Reimer T, Muller H, Kuchenmeister I, Makovitzky J, et al (2003). Skin-sparing mastectomy with conservation of the nipple-areola complex and autologous reconstruction is an oncologically safe procedure. Ann Surg 238(1):120-7.

35. Kroll SS, Khoo A, Singletary SE, Ames FC, Wang BG, Reece GP, et al (1999). Local recurrence risk after skin-sparing and conventional mastectomy: a 6-year follow-up. Plast Reconstr Surg 104(2):421-5.

36. Vaughan A, Dietz JR, Aft R, Gillanders WE, Eberlein T J, Freer P, et al (2007). Scientific Presentation Award. Patterns of local breast cancer recurrence after skin-sparing mastectomy and immediate breast reconstruction. Am J Surg 194(4): 438-43.

37. Spiegel AJ, Butler CE (2003). Recurrence following treatment of ductal carcinoma in situ with skin-sparing mastectomy and immediate breast reconstruction. Plast Reconstr Surg 111(2): 706-11.

38. Greenway RM, Schlossberg L, Dooley WC (2005) Fifteen-year series of skinsparing mastectomy for stage 0 to 2 breast cancer. Am J Surg 190(6):918-22. 
39. Meretoja TJ, von Smitten KA, Leidenius MH, Svarvar C, Heikkila PS, Jahkola, T, et al (2007). Local recurrence of stage 1 and 2 breast cancer after skin-sparing mastectomy and immediate breast reconstruction in a 15 -year series. Eur J Surg Oncol 33(10):1142-5.

40. Kim HJ , Park EH, Lim WS, Seo JY, Koh BS, Lee TJ, et al (2010) Nipple areola skin-sparing mastectomy with immediate transverse rectus abdominis musculocutaneous flap reconstruction is an oncologically safe procedure: a single center study. Ann Surg. 251(3): 493-8.

41. Cheung KL, Blamey RW, Robertson JF, Elston CW, Ellis IO, et al (1997). Subcutaneous mastectomy for primary breast cancer and ductal carcinoma in situ. Eur J Surg Oncol 23(4): 343-7.

42. Petit JY, Veronesi U, Orecchia R, Rey P, Martella S, Didier F, et al (2009). Nipple sparing mastectomy with nipple areola intraoperative radiotherapy: one thousand and one cases of a five years experience at the European institute of oncology of Milan (EIO). Breast Cancer Res Treat, 117(2): 333-8.

43. Crowe JP, Patrick RJ, Yetman RJ, Djohan R, et al (2008). Nipple-sparing mastectomy update: one hundred forty-nine procedures and clinical outcomes. Arch Surg 143(11): 1106-10; discussion 1110.

44. Benediktsson KP, Perbeck L (2008). Survival in breast cancer after nipple-sparing subcutaneous mastectomy and immediate reconstruction with implants: a prospective trial with 13 years median follow-up in 216 patients. Eur J Surg Oncol 34(2):143-8. 